\title{
О выпуске
}

Тема этого номера «Социальная активность и трансформации идентичностей: процессы в России и Евросоюзе». Пандемия COVID-19 запустила процессы изменений в социуме практически в планетарном масштабе. Резко и едва ли не повсеместно выросла социальная и политическая активность. В ряде стран она приобрела радикально протестные формы. Существенно ускорились и без того достаточно бурные изменения различных идентичностей, что в числе прочего обусловлено экономическими и политическими переменами. По этой причине в данном выпуске «Вестника» центральное место занимают работы, в которых рассматриваются экономические аспекты гендерных проблем в России (на примере одного из самых развитых и влиятельных субъектов федерации Республики Татарстан), отношение молодёжи Европы к европейской идентичности, а также социальная активность в российском обществе и протестные настроения молодёжи российского Дальнего Востока.

Рубрику открывает последняя работа ушедшего от нас Владимира Васильевича Петухова, написанная в соавторстве с Петуховым Р. В. (Москва) «Социально активные группы российского общества: формирование запроса на демократическое участие». В статье на основании данных массовых опросов оценивается степень политизации и включённости в практики гражданского участия социальной группы «профессионалов», под которыми подразумеваются россияне, имеющие высшее образование и, как правило, зарабатывающие деньги умственным трудом.

В российских реалиях представители этой группы в течение долгого времени были ориентированы на индивидуальную самореализацию и сторонились участия в общественно-политической жизни страны, однако в последние несколько лет, как показывают исследования ФНИСЦ РАН, они начали формировать запрос на демократическое участие. Авторы полагают, что это запрос не только на адекватное представительство интересов этих групп во власти, но и на изменение самого характера взаимоотношений общества и государства. Непосредственная включённость «профессионалов» в практики политического и социального участия пока является их реакцией на те или иные политические события, которые им представляются важными, однако в случае же дальнейшего ухудшения общественно-политической среды и снижения уровня жизни в стране, их «фоновый» интерес может трансформироваться в систематические и более активные практики политического участия.

В статье Викторовой Е. В., Петренко Д. А., Власовой Н. В. (СанктПетербург) «Процессы интеграции и идентичность: взгляд молодёжи Европы» на основе материалов эмпирического исследования рассматри- 
вается концепция европейской идентичности и отношение к евроинтеграции представителей европейской молодёжи. В качестве целевой группы исследования выбраны студенты европейских стран, так как их мировоззрение сложилось в условиях объединённой Европы. Результаты исследования показали, что респонденты, идентифицируя себя как европейцев, отмечают, что национальная идентичность для них остаётся более значимой. Среди элементов европейской идентичности респонденты называют прежде всего европейские ценности (мобильность, свободу, демократию), а также культурные (религия) и поведенческие характеристики (любовь к путешествиям).

В работе Марина Е. Б. (Владивосток) «Представление о социальном протесте у молодёжи российского Дальнего Востока» содержатся результаты семантической реконструкции представлений о различных формах социального протеста у молодёжи двух возрастных групп города Владивостока (18-24 и 25-30 лет). Автором реконструированы структурно-содержательные характеристики представлений молодёжи о пяти значимых формах коллективного протеста: петиции, митинге, забастовке, бунте и восстании. Были выявлены смысловые связи форм протеста с экзистенциальными и политическими ценностями молодёжи, а также эмоциональный компонент представлений о протестных феноменах. Сравнительный анализ представлений о разных формах протеста показывает, что митинг наиболее близок молодёжи на эмоциональном уровне. На рациональном уровне положительно оценивается и петиция, но при этом молодёжь обеих групп недовольна неэффективностью её на практике. Молодые люди не связывают радикальные формы протеста (бунт и восстание) со значимыми для себя ценностями и целями, воспринимают их негативно.

В статье Гневашевой В.А. и Ильдархановой Ч. И. (Казань) «Типовые социально-экономические поведенческие ориентации женщин на республиканском рынке труда Татарстана» представлены результаты авторского исследования, направленного на определение поведенческих траекторий женщин как значимого демографического сегмента, дифференцированного по гендерному признаку, и на выявление его значимости для процесса формирования и трансформации рыночного механизма рынка труда Республики Татарстан. Были выделены основные типы трудового поведения женщин республики: материально ориентированный, «здоровьесохранный», «семейно центрированный» и профессионально направленный. Исследование показало, что большинство женщин стремится совмещать работу с уходом за детьми, а молодое поколение женщин Республики Татарстан ориентировано на трудовую деятельность больше, чем на репродуктивную.

Рубрика «Социальные коммуникации в условиях “цифровой экспансии"» представлена тремя статьями, в которых интересна не только современная тематика исследований, но и используемые методы. В условиях ограничений, связанных с пандемией, классические социологические исследования оказались затруднены. По этой причине социологи 
активно использовали смысловой анализ текстов в интернет, онлайн опросы и инновационные для социологии способы сбора данных, например, медиааналитика и нейрофизиологическое исследование визуального контента.

Статья Артюшиной Е. В. и Кореньковой М. М. (Нижний Новгород) «Исследование факторов удовлетворённости потребителей развитием диджитал-коммуникаций: ожидания и реальность» анализирует новые способы, к которым прибегают компании для того, чтобы доставить своё сообщение существующему или потенциальному клиенту, а также оценки потребителями некоторых из этих способов. Авторы попытались выявить факторы, влияющие на удовлетворённость потребителей коммуникацией с компаниями в цифровой среде. Маркетинговое по форме исследование позволило изучить социальные аспекты цифровизации и автоматизации коммуникаций компании с клиентами, более того, - рассмотреть на конкретных примерах проблему, выходящую далеко за пределы коммерческого взаимодействия - отношение людей к общению с автоматом, по сути, с роботом. Обнаружена низкая степень удовлетворённости новыми, цифровыми способами коммуникационного взаимодействия между компаниями и пользователями, заменой живого общения автоответчиком.

Статья Ярмак О. В., Большаковой М. Г., Шкайдеровой Т. В., Маранчак А. Г. (Севастополь) «Социальные парадоксы коммуникации в постконфликтных обществах» посвящена теме крайне сложной и по целому ряду причин, включая политические, малоизученной. По мнению авторов, актуальность исследования постконфликтных обществ продиктована тем, что в цифровую эпоху эффективное силовое решение должно подкрепляться участием в формировании информационной повестки и управлением информационными потоками. Результаты социальной медиааналитики информационных потоков на Украине и в Крыму, осуществлённой авторами, показали, что в кризисных условиях в социуме формируются коммуникативные сети, которые создаются главным образом благодаря внешнему влиянию. Анализ выявленных потоков, представляющих коммуникативные сетевые конструкции, свидетельствует о различном генезисе их возникновения и функционирования, но определяющим в этом процессе является геополитический запрос на формирование медиатреков. Информационные потоки постконфликтных обществ выступают коммуникативно-политическими структурами, имеющими двойную природу: изначально несут идеи открытого и демократического общества, но затем формируют конфликтные ситуации в гражданском и медийном полях.

В статье Ерёменко Ю. А. и ЖТаворонковой 3. А. (Симферополь) «Нейрофизиологические исследования восприятия визуального политического контента в социальных сетях" рассмотрены особенности молодёжного восприятия политического контента. Авторами использован нейрофизиологический метод окулографии для изучения визуального внимания, эмпирической базой исследования послужил анализ 1500 постов социальных сетей политической направленности, к которым 
было применено тегирование визуальной части сообщения и собрана базовая поведенческая статистика, включающая показатели коммуникабельности, привлекательности и вирусности. Это позволило произвести первичную типологизацию политического контента и сформировать наборы стимульного материала для проведения нейрофизиологического исследования. Полученные количественные данные позволили определить траекторию изучения стимульного материала, а также оценить визуальное внимание при восприятии различного вида политического контента. Авторы установили, что наибольший интерес представляют мемы и фотографии политических лидеров, наименьший - плакаты.

В рубрике «Трибуна молодого учёного» стало традицией публиковать статьи, которые являются своего рода «пробой пера». В этом выпуске она представлена статьей Морозова И. С. (Москва) «Социологический подход к анализу структурированной внеучебной деятельности и школьной успеваемости среди детей с ограниченными возможностями здоровья», основанной на дипломном проекте автора. В работе рассматривается вопрос о связи структурированных внеучебных занятий и успеваемости детей с ограниченными возможностями здоровья. В выборку проведённого автором исследования вошли обучающиеся по коррекционным программам в школе-интернате российского города-миллионника. Результаты анализа показали, что у детей с психическими нарушениями как в начальной, так и в средней школе продолжительность занятий в художественных секциях положительно связана с их школьной успеваемостью, что говорит о важности таких занятий для достижения успехов в обучении и, как следствие, для успешной адаптации к жизни после школы. Занятия в спортивных секциях значимо не сказываются на школьной успеваемости детей из данной выборки, но и не оказывают негативного влияния.

Завершает выпуск рубрика «Новости науки». В статье Антонова Н. С., Бадараева Д. Д и Бадонова А. М. (Улан-Удэ) «Обсуждение вопросов социальной безопасности и социальной защиты населения в современных условиях" представлен обзор конференции «Социальная безопасность и социальная защита населения в современных условиях", прошедшей недавно в г. Улан-Удэ (Республика. Бурятия), посвящённой 20-летию социально-психологического факультета и 25-летию специальности «Социальная работа» в Бурятском государственном университете им. Д. Банзарова. На конференции были заслушаны доклады, в которых отражены различные аспекты социальной безопасности и социальной защиты населения в современных условиях.

Статья Мухановой М. Н. (Москва) «Обзор методологических подходов к анализу трансформации аграрного рынка труда в современной России» посвящена отечественным исследованиям трансформации аграрного рынка труда в постсоветский период. Исследователи российского села в основном описывают проблемы, связанные с российским селом и аграрным рынком труда: разрушение инфраструктуры на сельских территориях, бедность, безработица, взаимодействие старых и новых 
субъектов производства СХО, КФХ, ЛПХ и агрохолдингов, потеря связи селян с сельхозпредприятиями, их модели адаптации и трудового поведения. Результаты обзора их работ показали, что в настоящий период курс государства, направленный на преобразование институтов АПК и формирование новых субъектов производства, оказался оправданным в части усиления защиты внутреннего рынка, вследствие чего были выполнены основные задачи - импортозамещение и наполнение рынка отечественной продукцией, что обусловило движение к экспортному рынку. 